\title{
Influence of different media on growth, biomass production, sporulation and concentrations of liquid form of Nomuraea rileyi inoculum's on its growth, development and bioefficacy against Spodoptera litura
}

S.D. PATIL

Department of Entomology, Agricultural Research Station, Niphad, NASIK (M.S.) INDIA

\section{ARITCLE INFO}

Received : 10.06 .2015

Revised : 10.08 .2015

Accepted : 25.08.2015

\section{KEY WORDS :}

Nomuraea rileyi, Media, Yeast extract, Biomass, Colony forming unit, Spodoptera litura

Author for Correspondence :

Email: saurushrutu@gmail.com

\begin{abstract}
The entomopathogenic fungus, Nomuraea rileyi (Farlow) Samson was mass produced in different liquid media. The nine media of various nutrient sources were evaluated to find out most suitable medium for growth, biomass and viability of N.rileyi. Sabouraud's dextrose broth with yeast extract proved to be superior which gave significantly highest $\mathrm{cfu}\left(8.33 \times 10^{8} / \mathrm{ml}\right)$ and biomass $(6.10 \mathrm{~g})$. The next best medium was Sabouraud's maltose broth with yeast extract and potato dextrose broth with yeast extract which registering cfu count of $\left(7.33 \times 10^{8}\right.$ and $\left.5.67 \times 10^{8} \mathrm{cfu} / \mathrm{ml}\right)$ and biomass $(5.63$ and $4.20 \mathrm{~g})$, respectively. The lowest $(21.67 \%)$ medium surface coverage and least biomass $(1.04 \mathrm{~g})$ and cfu $\left(2.33 \times 10^{8} / \mathrm{ml}\right)$ were registered in medium with malt extract. Thus, considering growth, development and viability of N.rileyi Sabouraud's dextrose broth with yeast extract (SDY) emerged as the most potential medium for biomass production and sporulation. The growth of N.rileyi increased with increase in concentration of inoculums in Sabouraud's dextrose broth with yeast extract. N. rileyi $\left(2 \times 10^{9}\right) 90.0$ per cent produced highest biomass $(11.17 \mathrm{~g})$. However, it was at par with 30.0 to 80.0 per cent N.rileyi producing the fungal biomass of 10.57 to $11.07 \mathrm{~g}$, respectively. The biomass at $10 \mathrm{DAI}$ was lowest $7.63 \mathrm{~g}$ in concentration of 10.0 per cent. Maximum $\left(21.67 \times 10^{8} \mathrm{cfu} / \mathrm{ml}\right) \mathrm{cfu}$ count was registered in 50 per cent concentration of $N$.rileyi aqua suspension. However, it was at par with that in 40 per cent $\left(20.67 \times 10^{8} \mathrm{cfu} / \mathrm{ml}\right)$ and 30 per cent $\left(19.67 \times 10^{8} \mathrm{cfu} / \mathrm{ml}\right)$ inoculums of aqua suspension. The increase in concentration of N.rileyi culture from 10 per cent ( $\mathrm{pH} 8.04)$ to 90 per cent ( $\mathrm{pH}$ 8.84) there was gradual increase in $\mathrm{pH}$ as compared the SDY medium $\mathrm{pH}$ (6.46) measured before adding the inoculum. Studies carried out under laboratory condition to know dose mortality response between different instars of S.litura and N.rileyi indicated that fungus performed better at its higher. Concentration $\left(1.8 \times 10^{7} \mathrm{cfu} / \mathrm{ml}\right)$ compared to lower concentrations viz., $2.0 \times 10^{6}$ to $1.6 \times 10^{7} \mathrm{cfu} / \mathrm{ml}$. the N.rileyi was found to be highly effective to early instars of S.litura.
\end{abstract}

How to view point the article : Patil, S.D. (2015). Influence of different media on growth, biomass production, sporulation and concentrations of liquid form of Nomuraea rileyi inoculum's on its growth, development and bioefficacy against Spodoptera litura. Internat. J. Plant Protec., 8(2) : 288-294. 